\title{
Delayed diagnosis of Angioimmunoblast T- cell lymphoma presenting with type II Cryoglobulinemia and acute kidney injury: a case report and narrative review of the literature
}

\author{
Xiang-Yang Li ${ }^{1}$ (D), Hai-Yan He ${ }^{1}$ (D), Shu-Ling Yue ${ }^{2}$ (D) and Pearl Pai ${ }^{1,3^{*}}$ (i)
}

\begin{abstract}
Background: Angioimmunoblastic T cell lymphoma (AITL) is an infrequent hematological malignancy with variable and often atypical presentations. The presence of dysproteinemia, autoantibodies and systemic involvement in AITL has often led to a delay in diagnosis or even misdiagnosis in practice. We herewith present a case of AITL that primarily presented with acute kidney injury associated with type II Cryoglobulinemia, the underlying cause was only identified 8 months after the emergence of initial symptoms.

Case presentation: A 67-year old woman presented with 2-month history of intermittent joint pain and a 3-day history of bilateral lower limb edema and acute kidney injury. Initial laboratory investigations showed marked hypocomplementemia with positive autoantibodies of ANA, anti-cardiolipin-IgM and direct antiglobulin. The serum and urinary Immunofixation and serum cryoglobulin tests were negative, while the serum free $\mathrm{k}$ to $\lambda$ light chain ratio was 0.231 . A renal biopsy showed a diffuse proliferative glomerulonephritis with intracapillary pseudothrombi formation. There were orderly arranged microtubular structures of 20-35 nm in diameter in the subendothelial and mesangial area on electron microscopy. Shortly afterwards, the patient developed tingling affecting her finger tips and weak hands and legs. A diagnosis of cryoglobulinemia complicated with cryoglobulinemic glomerulonephritis and polyneuropathy was made. She responded well to methylprednisolone, plasma exchange and rituximab. However, 3 months later, she presented with generalized pruritic rash, weight loss, and inguinal lymphadenopathy. A subsequent inguinal excisional lymph node biopsy at month 8 revealed AITL as the underlying disease.
\end{abstract}

Conclusions: AITL and its associated B cell dysregulation can give rise to autoimmunity and cryoglobulinemia which may conceal itself as the underlying disorder. In various clinical scenarios of auto-immune diseases, it is advisable that the clinicians should take into consideration the multi-faceted lymphoma.

Keywords: Angioimmunoblastic T cell lymphoma, Dysgammaglobulinemia, Autoantibody, Dysimmunity, Autoimmunity, Monoclonal gammopathy, Cryoglobulinemia, Glomerulonephritis, Cryoglobulinemic syndrome

\footnotetext{
* Correspondence: ppai1@hku.hk

'Department of Nephrology, University of Hong Kong - Shenzhen Hospital, Shenzhen, China

${ }^{3}$ Department of Medicine, University of Hong Kong - Queen Mary Hospital, Pokfulam Road, Hong Kong, China

Full list of author information is available at the end of the article
}

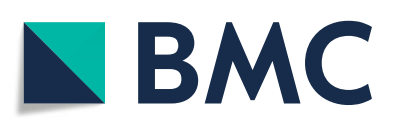

(- The Author(s). 2020 Open Access This article is licensed under a Creative Commons Attribution 4.0 International License, which permits use, sharing, adaptation, distribution and reproduction in any medium or format, as long as you give appropriate credit to the original author(s) and the source, provide a link to the Creative Commons licence, and indicate if changes were made. The images or other third party material in this article are included in the article's Creative Commons licence, unless indicated otherwise in a credit line to the material. If material is not included in the article's Creative Commons licence and your intended use is not permitted by statutory regulation or exceeds the permitted use, you will need to obtain permission directly from the copyright holder. To view a copy of this licence, visit http://creativecommons.org/licenses/by/4.0/ The Creative Commons Public Domain Dedication waiver (http://creativecommons.org/publicdomain/zero/1.0/) applies to the data made available in this article, unless otherwise stated in a credit line to the data. 


\section{Background}

AITL belongs to the non-Hodgkin's lymphoma (NHL) and is one of the more common subtypes of peripheral $\mathrm{T}$ cell lymphoma (PTCL), accounting for 15 to $20 \%$ of PTCL and 1 to $2 \%$ of NHL [1]. It is more prevalent in the elderly. The median age of presentation is 62-67 years (range, 20-91), and there is a slight male predominance [2-5]. Cytogenetic study suggests that AITL originates from follicular helper $\mathrm{T}$ cell (Tfh). Tfh normally resides in the germinal centers (GCs) within B cell follicles of secondary lymphatic organs [6]. It is known to have derived from naive CD4+ T cell, and plays a crucial role in the GC formation and the modulation of $\mathrm{B}$ cell activation, clonal selection, immunoglobulin synthesis, and isotype switch, as well as in somatic hypermutation, based upon cellular interplays between Tfh, B cells and follicular dendritic cells [7]. In normal circumstances, only with the help of Tfh, B cells are able to achieve maturation and transformation into memory B cells and memory plasma cells. Neoplastic expansion of Tfh may result in exaggerated GC reaction, unchecked B cell clonal proliferation, impaired immune tolerance and dysgammaglobulinemia. Consequently, AITL commonly presents with multiple lymphadenopathy and dysproteinemia matching its former descriptions including angioimmunoblastic lymphadenopathy with dysproteinemia (AILD) and immunoblastic lymphadenopathy (IBL) [8]. Its clinical picture may include typical B symptoms of lymphoma such as weight loss, fever and night sweat, with hepatosplenomegaly, elevated lactate dehydrogenase (LDH) level, and features of humoral immunity disturbance and autoimmunity attributable to dysregulatory action of $\mathrm{T}$ cells on B cells.

According to reported cases, AITL and its associated conditions may affect the kidney through direct invasion, inducing proliferative or non-proliferative glomerular nephritis (GN), or interstitial nephritis, or vasculitis, or amyloidosis, or cryoglobulinemia $[9,10]$. We report here a case of a 67-year-old female with AITL that presented initially with a cryoglobulinemic glomerulonephritis, autoimmunity and polyneuropathy. A delayed diagnosis of AITL was made a few months later. This case demonstrates the importance of considering underlying lymphomatous diseases including AITL in unusual autoimmune diseases and cryoglobulinemia.

\section{Case presentation}

A 67-year old housewife was admitted to the Nephrology Department of our Hospital in December 2018 with 2-month history of intermittent mild to moderate joint pain affecting the right wrist and metacarpophalangeal joints of her right hand, and a 3-day history of bilateral lower limb edema. One month earlier, she underwent a MRI scan in a local hospital for her joint symptoms. The scan showed minor joint fluid with soft tissue swelling of her right wrist and slight degenerative change of her right hand's carpal bones. Her joint pain improved after some simple analgesia. She reported no rash, and no dry eyes and mouth. There was no parotid gland enlargement or neck swelling either. Ten days before her admission to our hospital, she developed a fever (maximum $38.9^{\circ} \mathrm{C}$ ) and cough with white sputum. A chest X-ray revealed increased bilateral lung markings. The blood leukocyte count was $7.9 \times 10^{9} / \mathrm{L}$ (normal $4.0-10.0 \times$ $10^{9} / \mathrm{L}$ ), hemoglobulin $(\mathrm{Hb}) 96 \mathrm{~g} / \mathrm{L}$ (normal 115-150 g/ $\mathrm{L}$ ), CRP level $54 \mathrm{mg} / \mathrm{L}$ (normal $0-10 \mathrm{mg} / \mathrm{L}$ ) and serum creatinine $67 \mu \mathrm{mol} / \mathrm{L}$ (normal $46-92 \mu \mathrm{mol} / \mathrm{L}$ ). Her cough and fever responded to a course of cefuroxime given for a suspected lower respiratory tract infection but her legs became increasingly swollen and her serum creatinine rose to $190 \mu \mathrm{mol} / \mathrm{L}$. She was thereafter admitted to our hospital. Her only past medical history was chronic hypertension that was wellcontrolled with $5 \mathrm{mg}$ amlodipine daily. She denied any self-medication. There was no significant family history.

At presentation, her temperature was $37^{\circ} \mathrm{C}$, BMI was $21.9 \mathrm{~kg} / \mathrm{m}^{2}$, and blood pressure was $118 / 70 \mathrm{mmHg}$. There was no skin rash or palpable lymphadenopathy. The lungs were clear with no audible heart murmur. The abdominal and neurological examinations were unremarkable. There was bilateral pitting edema from legs to the knees.

Table 1 summarized the results of her laboratory investigations following her admission into our hospital. Her admission full blood count showed a white blood cell (WBC) of $6.82 \times 10^{9} / \mathrm{L}$ (neutrophils $84 \%$; lymphocytes $12 \%$ ); red blood cell (RBC) $2.59 \times 10^{12} / \mathrm{L}$ $\left(3.87-5.11 \times 10^{12} / \mathrm{L}\right) ; \mathrm{HB} 75 \mathrm{~g} / \mathrm{L}(115-148)$; and platelet count (PLT) $219 \times 10^{9} / \mathrm{L}\left(162-341 \times 10^{9} / \mathrm{L}\right)$. Her blood film showed a schistocyte $<1 \%$. Urinalysis revealed trace proteinuria; urinary $\mathrm{WBC}$ was $13.5 / \mu \mathrm{l}$ (0-23); urinary $\mathrm{RBC}$ was $50.6 / \mu \mathrm{l}(0-18)$ and was dysmorphic in appearance. The urinary albumin to creatinine ratio (ACR) and protein to creatinine ratio (PCR) were $153.1 \mathrm{mg} / \mathrm{g}(<20)$ and $261 \mathrm{mg} / \mathrm{g}(<200)$ respectively. Serum CRP was $14.58 \mathrm{mg} / \mathrm{L}(0-5)$; and procalcitonin $(\mathrm{PCT})$ level was $1.02 \mathrm{ng} / \mathrm{ml}(<0.05)$. Her serum creatinine was $177 \mu \mathrm{mol} / \mathrm{L}(44-80)$; cystatin C $4.31 \mathrm{mg} / \mathrm{L}(\leq 1.03)$; blood urea nitrogen $(\mathrm{BUN}) 28.6$ $\mathrm{mmol} / \mathrm{L}(2.76-8.07)$; serum urate $636 \mu \mathrm{mol} / \mathrm{L}$ (142339); and LDH level was $268 \mathrm{U} / \mathrm{L}(135-214)$. The serum alanine aminotransferase (ALT) was $41 \mathrm{IU} / \mathrm{L}$ (9-52); aspartate aminotransferase (AST) $37 \mathrm{IU} / \mathrm{L}$ (14-36); while serum total protein was $55 \mathrm{~g} / \mathrm{L}$ (66- 
Table 1 Laboratory Data

\begin{tabular}{|c|c|c|c|}
\hline Variables & On admission & At discharge & Reference range \\
\hline$\overline{\mathrm{WBC} \times 10^{9} / \mathrm{L}}$ & 6.82 & 9.73 & $3.89-9.93$ \\
\hline Neutrophil \% & 84.0 & 82.9 & $44.0-72.0$ \\
\hline LYM \% & 12.0 & 8.4 & $20.0-45.0$ \\
\hline $\mathrm{RBC} \times 10^{12} / \mathrm{L}$ & 2.59 & 2.47 & $3.87-5.11$ \\
\hline $\mathrm{HB} g / \mathrm{L}$ & 75 & 74 & $115-148$ \\
\hline $\mathrm{PLT} \times 10^{9} / \mathrm{L}$ & 219 & 197 & $162-341$ \\
\hline urinary protein & Trace & Trace & Neg \\
\hline 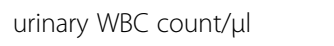 & 13.5 & 6.2 & $0-23$ \\
\hline 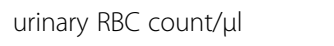 & 50.6 (dysmorphic) & 13.2 & $0-18$ \\
\hline $\mathrm{ACR}(\mathrm{mg} / \mathrm{g})$ & 153.1 & 120.8 & $<20$ \\
\hline$P C R(\mathrm{mg} / \mathrm{g})$ & 261 & 464.4 & $<200$ \\
\hline 24-h urinary albumin (mg) & 61.2 & 57.7 & $0-30$ \\
\hline 24-h urinary protein (mg) & 113.69 & 185 & $0-140$ \\
\hline Procalcitonin (PCT) $(\mathrm{ng} / \mathrm{ml})$ & 1.02 & / & $<0.05$ \\
\hline Serum CRP (mg/L) & 14.58 & 4.61 & $0-5$ \\
\hline $\operatorname{ESR}(\mathrm{mm} / \mathrm{h})$ & 70 & / & $0-20$ \\
\hline Sodium (mmol/L) & 120 & 141 & $136-145$ \\
\hline Potassium (mmol/L) & 4.53 & 3.45 & $3.5-5.1$ \\
\hline Urea (mmol/L) & 28.6 & 8.0 & $2.76-8.07$ \\
\hline Creatinine $\mu \mathrm{mol} / \mathrm{L}$ & 177 & 43 & $44-80$ \\
\hline eGFR (EPI) $\left(\mathrm{mL} / \mathrm{min} / 1.73 \mathrm{~m}^{2}\right)$ & 25.25 & 137.75 & $>90$ \\
\hline Bilirubin $(\mu \mathrm{mol} / \mathrm{L})$ & 8.1 & 5.6 & $0-21$ \\
\hline Total protein $(\mathrm{g} / \mathrm{L})$ & 55 & 43.6 & $66-87$ \\
\hline Albumin $(\mathrm{g} / \mathrm{L})$ & 28.9 & 24.7 & $35-52$ \\
\hline $\mathrm{ALT}(\mathrm{U} / \mathrm{L})$ & 41 & 18 & $9-52$ \\
\hline AST (U/L) & 37 & 19.7 & $14-36$ \\
\hline GGT (U/L) & 38.6 & 135.2 & $0-40$ \\
\hline $\mathrm{ALP}(\mathrm{U} / \mathrm{L})$ & 84 & 107 & $35-105$ \\
\hline Calcium (mmol/L) & 1.85 & / & $2.15-2.55$ \\
\hline $\mathrm{RF}(\mathrm{IU} / \mathrm{mL})$ & 9.5 & / & $0-14$ \\
\hline ANA & 1:320 & / & $<1: 100$ \\
\hline ENA & Negative & / & Undetectable \\
\hline ANCA $(\mathrm{U} / \mathrm{mL})$ & Negative & / & $0-20$ \\
\hline Anti-GBM (U/mL) & Negative & / & Undetectable \\
\hline$\beta 2-G P-1-A b$ & Positive & Negative & Undetectable \\
\hline Anti-cardiolipin-lgG & 1.21 & 1.14 & $0-12$ \\
\hline Anti-cardiolipin-IgM & 47.8 & 3.15 & $0-12$ \\
\hline Coomb's test & Positive & Negative & Negative \\
\hline C3 (g/L) & 0.26 & 0.46 & $0.9-1.8$ \\
\hline C4 (g/L) & 0.04 & 0.11 & $0.1-0.4$ \\
\hline $\lg M(g / L)$ & 4.14 & / & $0.40-2.30$ \\
\hline $\lg G(g / L)$ & 12.07 & / & $7-16$ \\
\hline $\lg A(g / L)$ & 1.11 & / & $0.7-4$ \\
\hline Serum IFE & Negative & / & Undetectable \\
\hline
\end{tabular}


Table 1 Laboratory Data (Continued)

\begin{tabular}{llll}
\hline Variables & On admission & At discharge & Reference range \\
\hline Urine IFE & Negative & $/$ & Undetectable \\
Free $\mathrm{K}$ light chain (mg/L) & 229.25 & $/$ & $3.30-19.40$ \\
Free $\lambda$ light chain (mg/L) & 992.5 & $/$ & $5.71-26.30$ \\
K to $\lambda$ ratio & 0.231 & $/$ & $0.26-1.65$ \\
HBV & HBsAg \& DNA negative; anti-HBc/anti-HBe negative & Undetectable \\
HCV-Ab & Negative & $/$ & Undetectable \\
HIV-Ab & Negative & Undetectable \\
\hline
\end{tabular}

Table 1 showed the laboratory investigations of the patient at the time of hospital admission and discharge.

Abbreviations: WBC White blood cell, HGB Hemoglobulin, PLT Platelet count, NEUT Neutrophil, LYM Lymphocyte, ACR urinary albumin-creatinine ratio, PCR urinary protein-creatinine ratio, $P C T$ procalcitonin, $A L P$ alkaline phosphatase, $A L T$ alanine aminotransferase, anti-GBM anti-glomerular basement membrane antibody, anti$H B C$ antibodies to hepatitis B core antigen, AST aspartate aminotransferase, C3 complement C3, C4 complement C4, dsDNA double-stranded DNA, eGFR estimated glomerular filtration rate, ENA extractable nuclear antigens, IFE immunofixation electrophoresis, GGT $\gamma$-glutamyl transferase, $H B s A g$ hepatitis B surface antigen, $H B V$ hepatitis B virus, HCV hepatitis C virus, HIV human immunodeficiency virus, IgM immunoglobulin M, RF rheumatoid factor, "/" denotes not available

87); and albumin $28.9 \mathrm{~g} / \mathrm{L}$ (35-52). The clotting profile was within normal range.

Her serum immunoglobulin (Ig) $\mathrm{M}$ was elevated at $4.14 \mathrm{~g} / \mathrm{L}(0.4-2.3) ; \operatorname{IgG} 12.07 \mathrm{~g} / \mathrm{L}$ (7-16); and IgA $1.11 \mathrm{~g} /$ L (0.7-4.0). Serum C3 level was $0.26 \mathrm{~g} / \mathrm{L}(0.9-1.8)$; C4 level was $0.04 \mathrm{~g} / \mathrm{L} \quad(0.1-0.4)$, anti-nuclear antibody (ANA) was 1:320 $(<1: 100)$; and rheumatoid factor (RF) was $9.5 \mathrm{IU} / \mathrm{ml}(0-14)$. The ENAs (extractable nuclear antigens), anti-double strand DNA (anti-dsDNA), antineutrophil cytoplasmic antibodies (ANCAs) and antiglomerular basement antibody (anti-GBM) were all negative. The anti-cardiolipin-IgM was $47.8 \mathrm{U} / \mathrm{ml}(0-$ 12). Anti- $\beta 1$ glycoprotein and direct antiglobulin test (Coomb's test) were positive. Anti-cardiolipin-IgG and lupus anticoagulant were negative. Both serum and urinary immunofixation were negative. The serum free $\mathrm{K}$ and $\lambda$ light chain levels were $229.25 \mathrm{mg} / \mathrm{L}$ (3.3-19.4) and $992.5 \mathrm{mg} / \mathrm{L}(5.71-26.3)$ respectively with a free $\kappa$ to $\lambda$ ratio of 0.231 (0.26-1.65 with normal kidney function, 0.37-3.1 with kidney dysfunction). Serum ferritin was $523.6 \mathrm{mg} / \mathrm{L}$ (11-306.8); tumor markers were negative. There was no evidence of past or present viral (V) hepatitis $(\mathrm{H})$ infection with negative anti-HCV, HBsAg, anti$\mathrm{HBsAb}, \mathrm{HBeAg}$, anti-HBeAb, anti-HBcAb. Human immunodeficiency virus (HIV) antibody, syphilis TP-EIA (treponemal-specific enzyme immunoassay), Cytomegalovirus (CMV)-DNA and Epstein-Barr (EBV)-DNA studies were all negative. The first serum cryoglobulin (blood sample obtained on day 12) was negative. Bone marrow biopsy performed on day 5 showed hypercellular marrow with erythropoietic stagnation. The flow cytometry study of a second bone marrow biopsy performed on day 33 did not reveal any phenotypic abnormalities associated with myeloma, lymphoma, leukemia or high risk myelodysplastic syndrome.

A chest and abdominal plain computed tomography (CT) scan taken earlier on day 2 showed patchy exudation along the bronchi and pulmonary blood vessels with small bilateral pleural effusion and a few small to medium size lymph nodes alongside the aortic arch, consistent with the picture of interstitial pneumonitis. There were no ascites or hepatosplenomegaly and no significant lymphadenopathy in the mediastinal, retroperitoneal or inguinal regions. Ultrasound scan showed normal appearance of both kidneys.

The patient was initially treated with intravenous (i.v.) amoxicillin clavulanate for a suspected respiratory tract infection and diuretics for her leg oedema. However, her serum creatinine rose further to $222 \mu \mathrm{mol} / \mathrm{L}$ and a renal biopsy was performed on day 9. The renal histopathology (Fig. 1) revealed a DPGN with intracapillary pseudothrombi formation. The light microscopy (LM) showed that 1 out of 17 glomeruli was sclerosed. There were marked endothelial and mesangial hypercellularity in the remaining 16 glomeruli (Figs. 1a-d). Congo-red stain was negative. There was no thickening or duplication of the glomerular basement membrane (GBM), and no significant epithelial proliferation or crescent formation (Figs. 1b-d). Notably, there was sporadic intraluminal hyaline thrombi formation within the glomerular tufts (Fig. 1d). There was only sporadic focal interstitial inflammatory cell infiltrate in the glomerular and tubular areas. There were signs of mild acute tubular injury, mild tubular atrophy, and about $10 \%$ interstitial sclerosis. Arteriolar wall thickening was seen occasionally. Paraffin immunofluorescence (IF) revealed granular deposition (on a 0 to $4+$ scale) of $2+$ IgM, $1+$ IgG, $1+$ C1q, $3+\mathrm{k}$ light chain and $1+\lambda$ light chain located within the intracapillary thrombi and in the capillary walls (Figs. 1e-h). IgG subclass levels of IgG1-4 were all negative (probably due to a weak IgG positivity of only $1+$ by paraffin embedded specimen, and IgG1-4 subclass intensity dispersion). Under electron microscopy (EM), capillary lobulation, localized endothelial proliferation and epithelial vacuolar degeneration could be seen. The GBM measured $400-700 \mathrm{~nm}$ in thickness. There were mesangial 

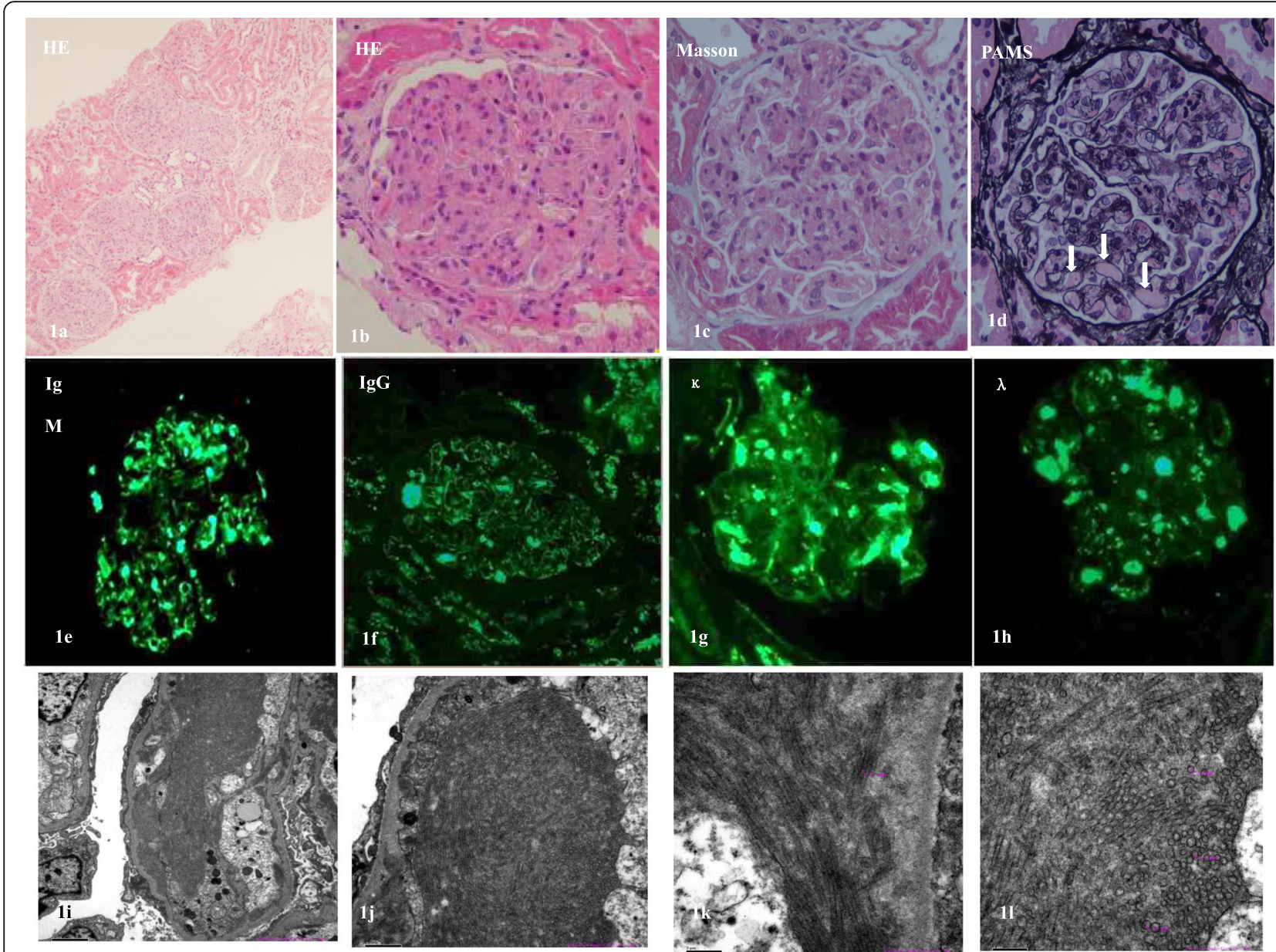

Fig. 1 Renal biopsy images. a-c Light microscopy showing significant endothelial and mesangial hypercellularity (Hematoxylin \& Eosin [H\&E] and Masson stains; $1 \mathrm{a} \times 100,1 \mathrm{~b}-\mathrm{c} \times 400$ ). $\mathbf{d}$ Light microscopy showing multiple intracapillary hyaline pseudothrombi formation (arrows) but no significant GBM duplication or thickening (Periodic Acid Methenamine [PAM] Silver stain, $\times 400)$. e-h Immunofluorescence microscopy indicates granular deposition of $\lg M 2+, \lg G 1+, \mathrm{k}$ light chain $3+$ and $\lambda$ light chain $1+$, located within the intracapillary thrombi and in the capillary walls $(x$ 400). (i-I) Micrographs of electron microscopy showing orderly arranged microtubular structures of $20-35 \mathrm{~nm}$ in diameter within the subendothelial and mesangial areas $(\times 5000)$

cellular and matrix expansion and segmental mesangial interposition, with diffuse podocyte foot process effacement. Orderly arranged microtubular structures of 20 $35 \mathrm{~nm}$ in diameter were seen in the subendothelial and mesangial area (Figs. 1i-l). The extent and degree of mesangial proliferation and interposition, and capillary wall double contouring were only insignificant or minor. Overall features considered, the final pathological diagnosis was considered as DPGN.

After 10 days of antibiotics and supportive therapy, the patient became increasingly oliguric with fluid overload. On day 11, acute intermittent hemodialysis (IHD) was initiated via a right internal jugular vein temporary dialysis catheter as the serum creatinine rose to $341 \mu \mathrm{mol} / \mathrm{L}$. On day 13, the patient complained about symmetrical tingling finger-tips and weak hands and legs. A sensory nerve and compound muscle action potential study was carried out which confirmed peripheral polyneuropathy. Meanwhile, her renal biopsy report indicated possibly cryoglobulinemic glomerulonephritis. As she had only recently recovered from a pulmonary infection, she was treated with i.v. methylprednisolone (MP) cautiously from day 14 to day 21 bringing the total treatment dose for this period to $1500 \mathrm{mg}$. Thereafter, the MP was reduced and maintained at $40 \mathrm{mg}$ daily. She was also given cotrimoxazole $480 \mathrm{mg}$ daily as a prophylaxis against Pneumocystis jirovecii. On day 15, she was started on a course of 5 sessions of PE therapy (3.0 L of equal volume fresh frozen plasma and $4 \%$ albumin solution, thriceweekly). On day 18 , she was given $600 \mathrm{mg}$ rituximab $\left(375 \mathrm{mg} / \mathrm{m}^{2}\right)$. The patient reported rapid improvement of her numbness and weakness after the steroid and PE. The IHD was discontinued on day 19. However, the patient's cough and sputum returned and the CRP level 
rose once more. Her serum CMV-DNA became positive with $7.23 \times 10^{2}$ copies $/ \mathrm{ml}$ and bronchoalveolar lavage fluid (BALF) culture yielded Candida albicans. She was treated with ganciclovir and voriconazole. Her chest imaging showed improvement but worsened again on day 29. The i.v. MP was reduced further to $20 \mathrm{mg}$ daily and she was put onto meropenem and voriconazole. On day 33, she was given i.v. immunoglobulin G (IVIG, $0.4 \mathrm{~g} / \mathrm{kg}$ ) for 3 days, after which her lungs and overall condition improved. Able to self-care, she was finally discharged home on day 53, despite a slight tingling in her finger tips. At the time of her discharge, her serum creatinine was $43 \mu \mathrm{mol} / \mathrm{L}$ and the $24 \mathrm{~h}$ urinary proteinuria and albuminuria were $185 \mathrm{mg}$ and $57.7 \mathrm{mg}$ respectively. Figure 2 showed the changes of her serum creatinine and C3 complement during her disease course. The discharged diagnosis was acute kidney injury due to mixed cryoglobulinemia, cryoglobulinemic diffuse proliferative glomerulonephritis, underlying monoclonal gammopathy, and interstitial pneumonitis. For personal reasons, the patient declined the suggestions of further MRI or positron emission tomography (PET)-CT scan to explore the cause of the monoclonal gammopathy.

The patient reported being well in the first two months post-discharge and her MP was gradually tapered to $8 \mathrm{mg}$ daily. At two months of discharge, her serum creatinine level was $68 \mu \mathrm{mol} / \mathrm{L}$; serum C3 was $0.65 \mathrm{~g} / \mathrm{L}$; peripheral WBC $8.03 \times 10^{9} / \mathrm{L}$; PLT count $273 \times$ $10^{9} / \mathrm{L}$; and $\mathrm{Hb} 103 \mathrm{~g} / \mathrm{L}$. However, at month 3 , she reported a generalized pruritic rash, polyarthralgia, weight loss, and groin lymphadenopathy. In June 2019, eight months after the onset of her joint pain, a PET-CT scan was finally taken and which showed extensive lymphadenopathy. An inguinal excisional lymph node biopsy was performed. The pathology reported diffuse effacement of nodal architecture with extensive infiltration of atypical lymphoid cells intermingled with proliferation of small blood vessels. The immunohistochemical study revealed CD3 (+), CD5 (+), CD20 (+), CD21 (+), CD23 $(+)$, CD38 (+), CD10 (+), CD13 (+), PD-1 (+), and BLC$6(+)$. The diagnosis was an AITL. The patient agreed to receive one course of CHOP (cyclophosphamide, doxorubicin, vincristine, prednisone) chemotherapy which seemed to have alleviated her symptoms.

\section{Discussion and conclusion}

\section{Discussion}

Lymphoma may affect the kidney tissue via a number of pathomechanisms that include direct invasion, lymphomatous infiltration [11], paraneoplastic syndrome [12] and parenchymal impairment resulted from diseaserelated dysimmunity, paraproteinemia and cryoglobulinemia $[9,13-15]$. It is worthy of note that the pathology of lymphoma-related renal diseases including AITL is multifarious and non-pathognomonic [9-11]. Both glomerular and tubulointerstitial compartments may be infiltrated by lymphomatous cells. If this should be the case, the application of immunophenotypic, cytogenetic or molecular studies on the atypical lymphocytes may be helpful in determining the diagnoses and assist their classification in a far better way than standard morphological studies $[13,16]$.

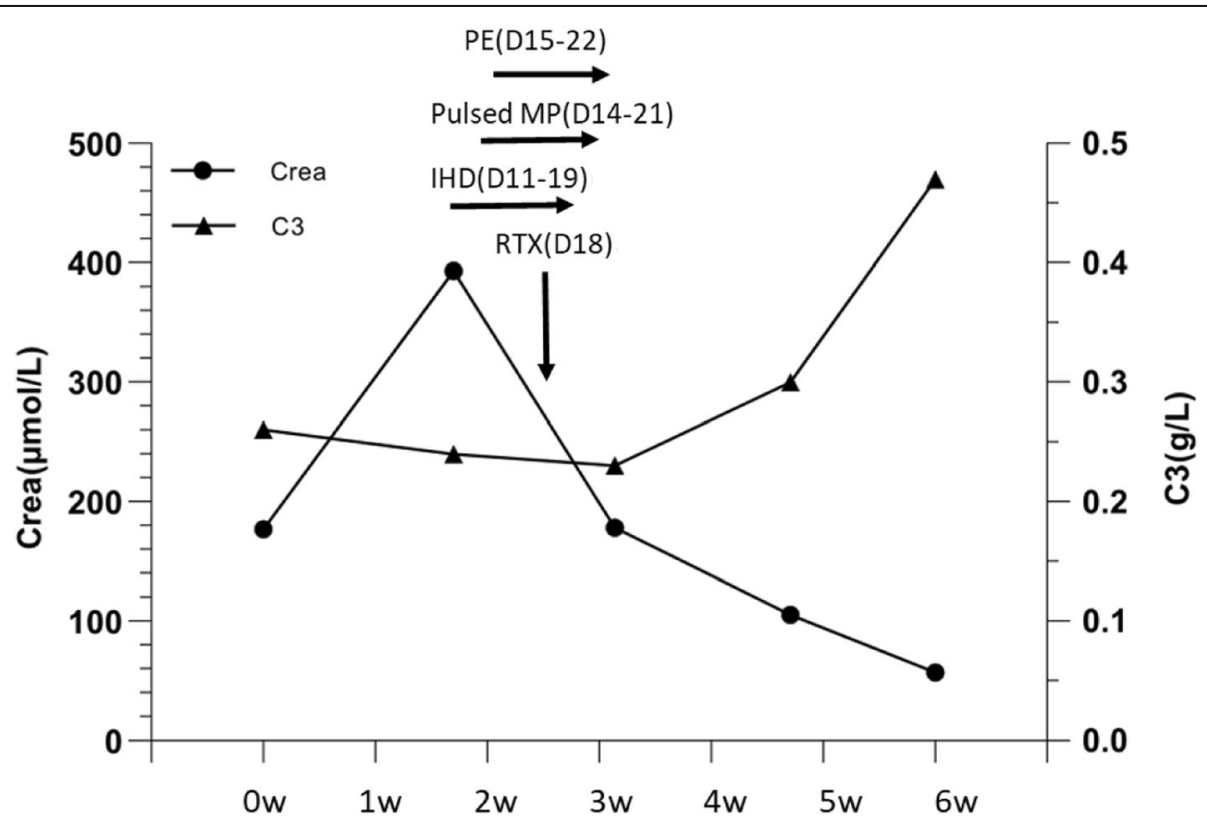

Fig. 2 The figure showed the changes of serum creatinine (Crea) and complement C3 during the first 6 weeks $(W$ ) in relation to the therapies and the day (D) they were given: Intermittent hemodialysis (IHD); pulsed methylprednisolone (MP); plasma exchange (PE); and rituximab (RTX) 
AITL was first introduced in 1974 by Frizzera et al. as AILD. The understanding of this disorder has since evolved from a non-malignant condition with neoplastic transformation potential to a hematological neoplasm often associated with aggressive course and unfavorable long-term outcome. The symptoms of AITL are variable and often atypical, and include generalized lymphadenopathy, systemic B symptoms, hepatosplenomegaly, skin rash, polyarthritis, anemia, and pleural effusion/ascites and so on $[8,17,18]$. In our case, the initial complaints were polyarthralgia and anemia which went on to involve the kidneys and the nervous system. Investigations revealed dysproteinemia, significant hypocomplementemia, cryoglobulinemic nephritis and acute kidney injury. The ultimate diagnosis of AITL was made 8 months later. A time lag in the diagnosis of AITL is not uncommon as the early symptoms may be multifarious and nonspecific in nature [8-10]. In a retrospective study of 77 AITL patients, the median time interval between first symptoms and diagnosis of AITL was reported as 3.6 months ( 1 to 36 months) while the median duration between the initial diagnosis and a final diagnosis of AITL was 2.3 months ( 0.4 to 29 months) [3].

The disease course of our case illustrated the features of AITL with variable initial presentations and humoral immunity dysfunction associated with dysregulated T-B cell regulation [8]. The anemia might have been related to the positive Coomb's test but the bone marrow biopsy finding of erythropoietic stagnation and suggestion of pure red cell anemia might have been resulted also from AITL related autoimmune process [19]. Although the serum cryoglobulin was negative in this case, the increased serum IgM, reduced C3 and C4 levels, and renal biopsy findings of endocapillary and mesangial proliferation with intracapillary pseudothrombi, and microtubular ultrastructure of subendothelial electron dense material were all indicative of cryoglobulinemic nephropathy $(\mathrm{CN})$. In fact, we have not been able to demonstrate any atypical lymphocytes in the renal pathology. There was insignificant inflammatory cell infiltrate in the tubulointerstitial or glomerular areas to allow definitive and comprehensive immunophenotypic or cytogenetic studies.

In order to provide a better understanding how AITL may affect the kidneys, we carried out a PubMed search on similar published reports concerning AITL and kidney involvement, using the MeSH terms of "AITL" or "AILD" or "IBL" and "kidney". As a result of the search, a flowchart of the literature search and a summary of the cases had been compiled, as shown in Table 2 and 3 . Hopefully, they might be helpful to show that the types of renal pathologies were variable and comprised an array of glomerular and interstitial lesions.

Cryoglobulinemia was classified by the Brouet criterion into 3 types, typeI, II, and III subtype. Their incidence respectively accounts for approximately $10-15 \%$, $60-70 \%$ and $20-30 \%$ of cryoglobulinemic syndrome [39]. Kidney is frequently affected in mixed (Type II and III) cryoglobulinemia, and to a lesser degree in typeIcryoglobulinemia $[40,41]$. The clinical spectrum of $\mathrm{CN}$ extends from isolated proteinuria and/or hematuria, acute and chronic nephritic syndrome to nephrotic syndrome. Cryoglobulin activates the complement and sparks off glomerular inflammation and subsequent glomerular proliferation. Our patient presented with mild micro-hematuria and proteinuria that progressed

Table 2 Obtainment of cases and articles.

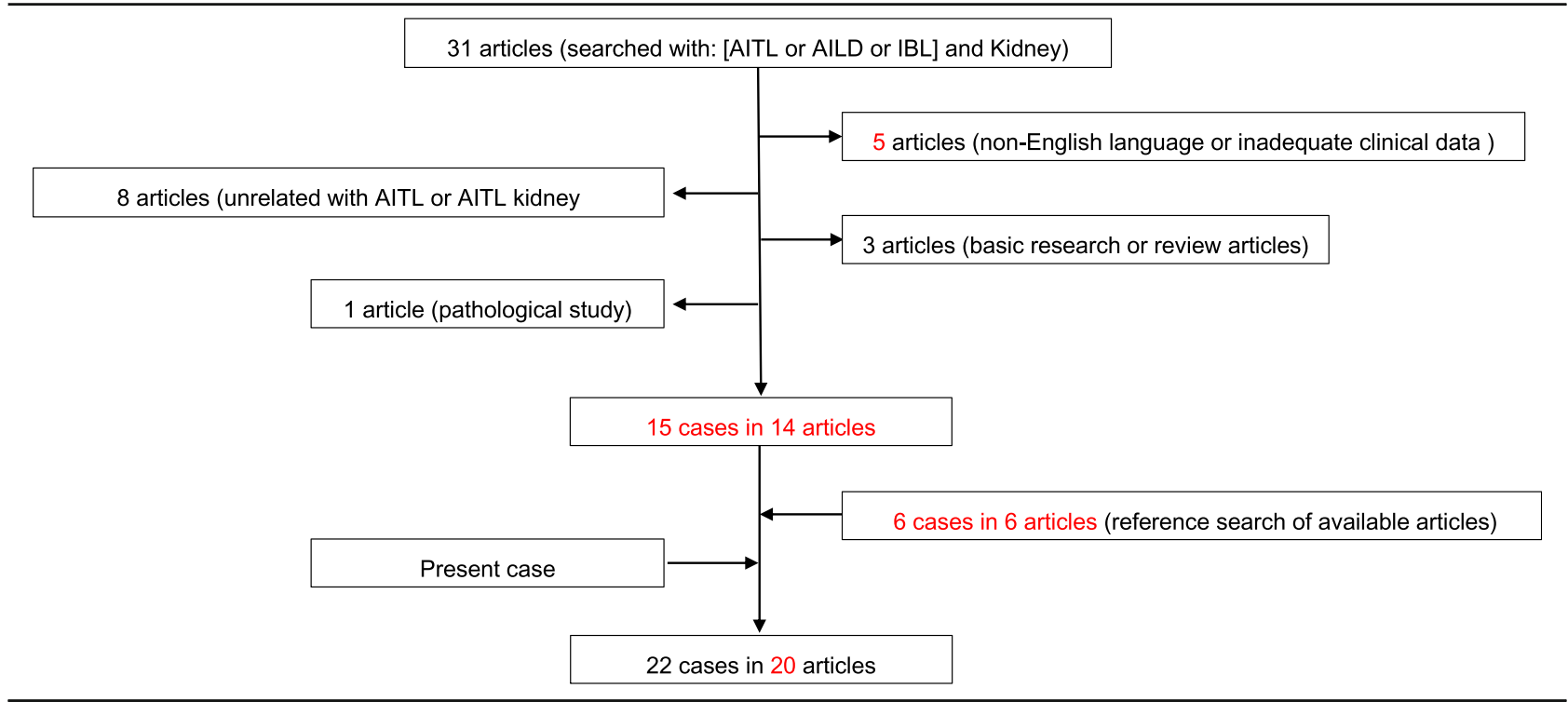

Abbreviations: AITL angioimmunoblastic T-cell lymphoma, AILD angioimmunoblastic lymphadenopathy with dysproteinemia, IBL immunoblastic lymphadenopathy 
Li et al. BMC Nephrology

(2020) 21:463

Page 8 of 12

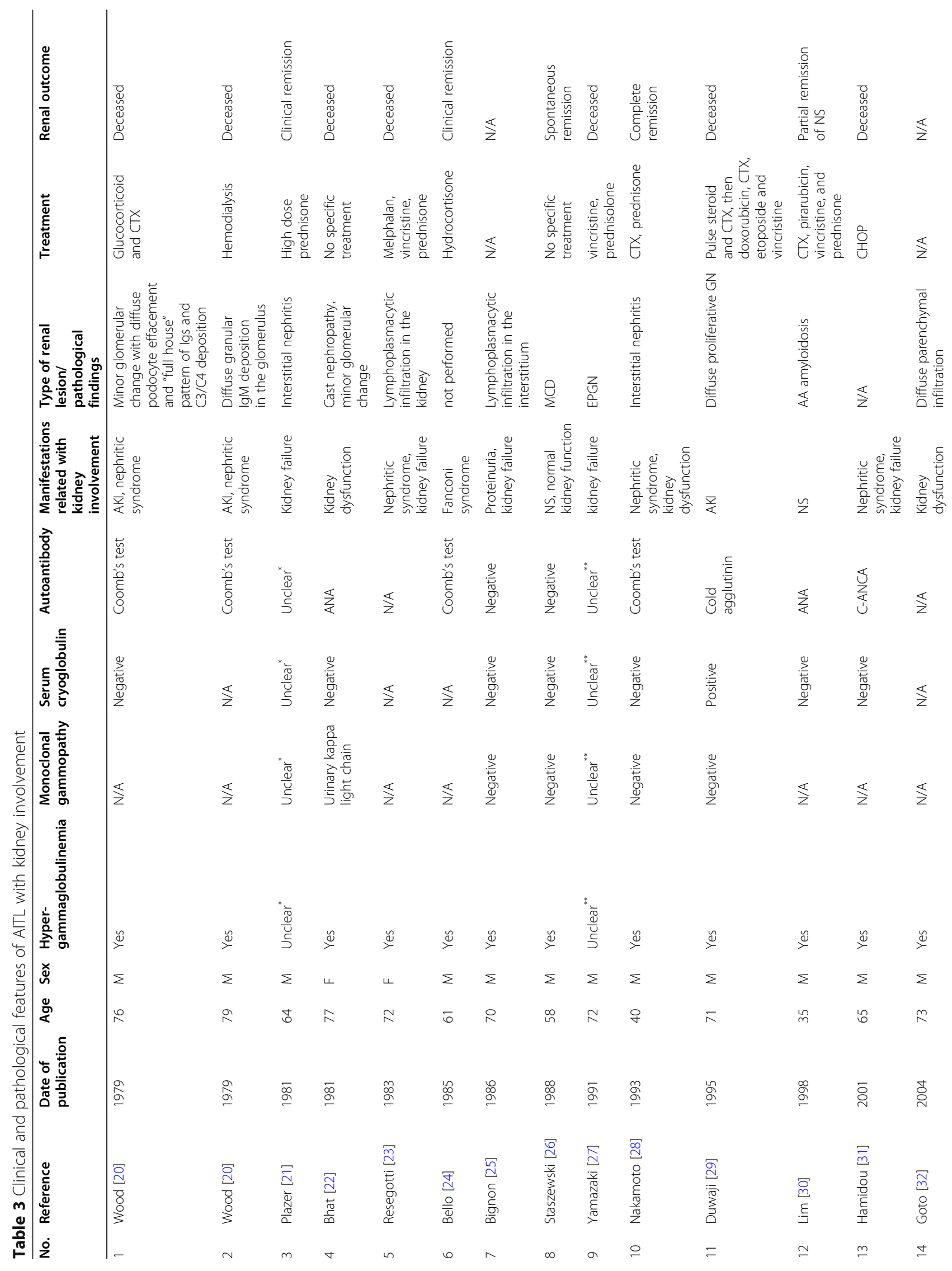


$\begin{array}{ll}\text { Li et al. BMC Nephrology } & \text { (2020) 21:463 }\end{array}$

Page 9 of 12

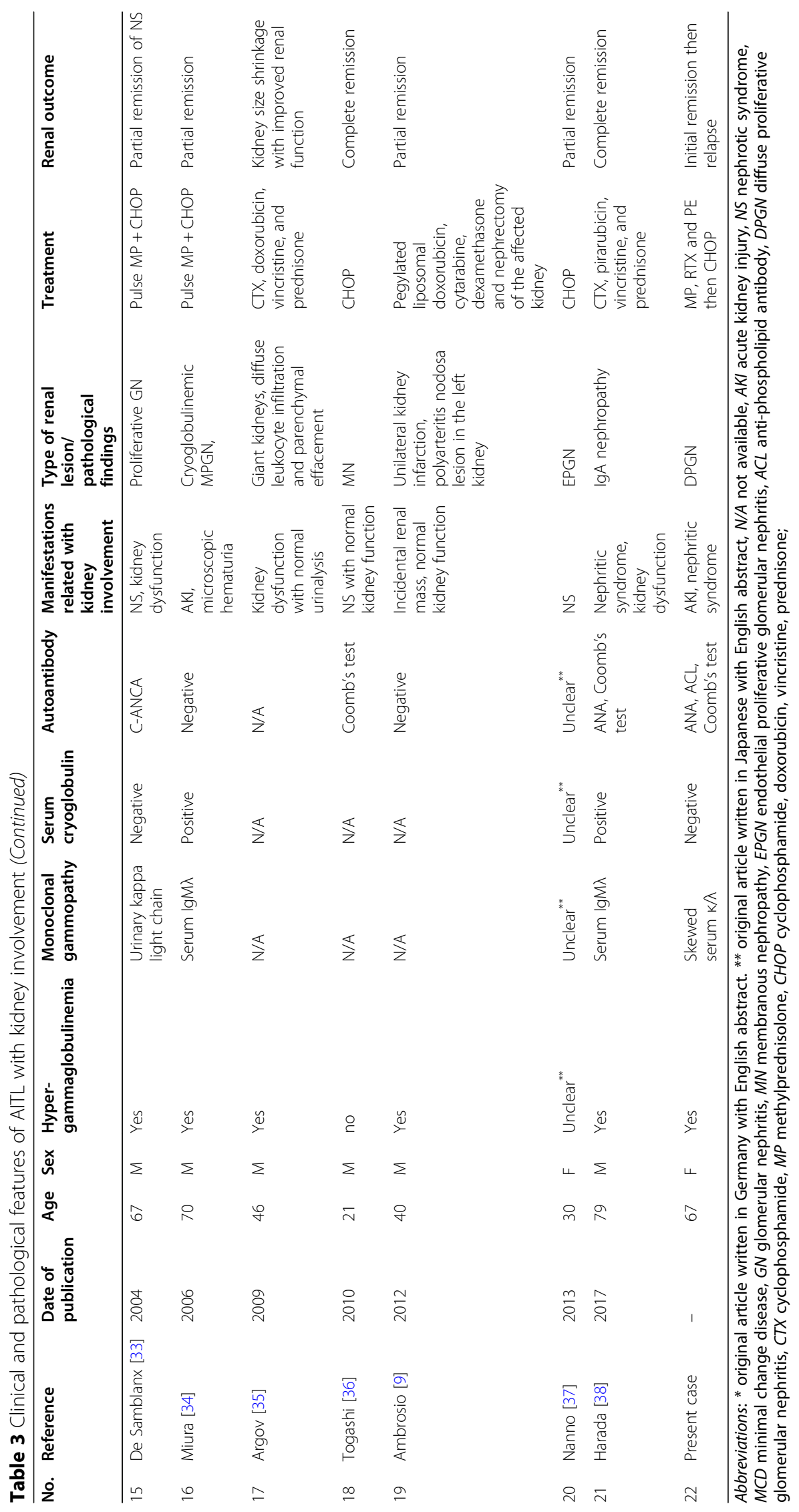


rapidly to renal failure. We suspect that the rapid deterioration of her glomerular filtration function was the result of capillary clog as well as a strong inflammatory reaction in the glomeruli. Although membranoproliferative glomerulonephritis (MPGN) is the predominant pathological phenotype accounting for 70 to $90 \%$ of all $\mathrm{CN}$ cases [39], other pathological types including endocapillary proliferative $\mathrm{GN}$, mesangial proliferative $\mathrm{GN}$, minimal change disease, and focal segmental glomerular sclerosis have been reported also [9, 19, 42], and they might correspond to a lower grade of inflammation and proliferation [43]. Interestingly, cellular phenotypic analysis has revealed that the endocapillary hypercellularity and capillary wall duplication in $\mathrm{CN}$ are sometimes the results of monocytic infiltration, rather than actual endothelial proliferation and mesangial cell and matrix interposition [43].

The mesangial proliferation in our biopsy is slight on LM but the presence of pseudothrombi has been shown as a key to the diagnosis of $\mathrm{CN}$. While cryoglobulin may precipitate either sub-endothelially or intra-luminally in the glomerular tuft [43], the presence of intraluminal pseudothrombi, a hallmark of $\mathrm{CN}$, is only observed in one third [43] to 50\% [44] of patients. In our case, the diagnosis of $\mathrm{CN}$ was further substantiated by electron microscopy (EM) findings. In cases of $\mathrm{CN}$, electron dense deposits can be found in all glomerular compartments of subendothelial, mesangial, and epimembranous areas. The most characteristic ultrastructure of cryoglobulin-containing deposit on EM has been found to be parallel-arrayed microtubular or curvilinear/annular structure which appears as cylindrical bodies measured $20-30 \mathrm{~nm}$ in diameter such as observed in our case. The annular or curvilinear structures are the crosssection of the curved hollow-centered cylinders [10, 43, 44]. Less common ultrastructure phenotypes include long straight parallel fibrils, short poorly oriented fibers in small bundles, and amorphous deposit [44]. The presence of osmiophilic bodies and crystalline inclusions in the endothelial and mesangial cells resulted from the phagocytosis of cryoprecipitate has lent support to the diagnosis of $\mathrm{CN}[42,44]$. Notably, Immunotactoid GN is characterized by glomerular microtubular structure which may be morphologically indistinguishable from that of $\mathrm{CN}$ but without the intracapillary thrombi. Additional clinical data are needed to distinguish the two entities while the presence of cryoglobulinemia and extra-renal involvement favor a $\mathrm{CN}$ diagnosis.

Although the detection of serum cryoglobulin supports the diagnosis of cryoglobulinemic disease, failure to detect cryoglobulin does not rule out cryoglobulinemia $[45,46]$. Cryoglobulins are temperature sensitive and difficult to be measured. Then the sensitivity of the test is low. For instance, the use of visual inspection of $1 \%$ or more cryocrit (considered positive) may negatively impact the test [46]. It is known that the serum level of cryoglobulin of an individual patient may fluctuate during the disease course [43]. Peripheral and end-organ entrapment of cryoglobulins may also result in a false negative. In our patient, any of the factors mentioned might have been contributory to our negative test result for serum cryoglobulin. To resolve these drawbacks, clinicians might turn to immunoelectrophoresis of Igs, histopathological evaluation of affected organs, and correlation of clinical data. In our patient, we deduced the presence of a circulatory monoclonal immunoglobulin (MIg), as indicated by a skewed serum free $\mathrm{k}$ to $\lambda$ light chain ratio. Since the tests of immunofixation and free light chain assays using serum or urine samples partially overlap each other, test of both should be performed to complement each other and enhance sensitivity [47]. In this case, we might postulate that the negative serum and urine immunofixation (room temperature) might have been resulted from cryoprecipitation of the monoclonal immunoglobulin.

Two bone marrow biopsy studies and a cytometry analysis of our patient have failed to support the diagnosis of a type I cryoglobulinemia, which is generally associated with MGUS or a B-cell lineage malignancy (such as multiple myeloma, Waldenström macroglobulinemia, or chronic lymphocytic leukemia). Type I cryoglobulinemia is typically characterized by the presence of high cryoglobulin concentration, hyperviscosity syndrome and frequent skin lesion. None of these were present in our case. The IF findings of our patient's kidney biopsy (IgM $2+, \operatorname{IgG1} 1+, \mathrm{C} 1 \mathrm{q} 1+$, with $\mathrm{k}$ light chain predominance; IgM, IgG, and light chains deposition in the intraluminal and subendothelial space) were suggestive of a mixed cryoglobulinemic nephritis. In our case, the skewed serum free light chain ratio argued against a type III cryoglobulinemia. We would argue strongly that our patient suffered most likely from Type II cryoglobulinemia associated with monoclonal IgMk and polyclonal IgG. The normal level of rheumatoid factor might have been resulted from end organ/kidney entrapment or consumption of IgM cryoglobulin. In a series of cases reported by Trejo et al. [19], 47/50 (94\%) cases of Type II cryoglobulinemia were composed of monoclonal IgMk and polyclonal IgG. In the same study, the rate of low serum C4 and C3 was 66.7 and 20.3\% respectively. The significantly depressed serum C3 and C4 levels in our patient indicated strong classical pathway activation and complement consumption that would have contributed to her AKI.

Due to abnormal T-cell/B-cell interaction and defective antibody production in AITL, dysproteinemia and autoantibodies are common in AITL. About $30-51 \%$ of AITL cases manifested hypergammaglobulinemia, and as 
many as $10-27 \%$ of patients demonstrated a detectable monoclonal gammopathy $[2,3]$. The dysregulated B-cell proliferation was probably the underlying cause of our patient's serum free light chain abnormality $(\kappa, 229.25$ $\mathrm{mg} / \mathrm{L} ; \lambda 992.5 \mathrm{mg} / \mathrm{L} ; \mathrm{k} / \lambda$ ratio of 0.231 ). The rapid response of our patient's kidney injury to therapies of pulsed steroid, RTX and PE could be explained by the potent suppression of glomerular inflammation, clearance of IgM-secreting monoclonal B cell clone, and rapid reduction of the circulatory cryoglobulin level. This combined immunosuppressive regimen has also been recommended in the management of other lifethreatening or rapidly progressive cryoglobulinemic diseases [48]. Unfortunately, our patient suffered a relapse a few months later. In a small cohort of 25 newly diagnosed patients with AITL, the addition of RTX to CHOP produced good short term response with no benefit on progression-free survival [49]. Like M-H Delfau-Larue et al. [49], we have also found it tempting to speculate that while RTX might have disrupted the T-cell/B-cell interaction and produced short term response, the persistent tumor microenvironment might have brought about a re-emergence of the lymphoma.

Effective and durable disease control of AITL depends on combined chemotherapy and/or autologous stem cell transplantation. CHOP regimen is commonly used as a standard treatment with complete remission rate of around 53\% [8]. In spite of active treatment, AITL has a 5 -year overall and failure-free survival of 33 and $18 \%$ respectively [2]. It looks as if that the long-term treatment of our patient relies on subsequent T-cell targeted consolidation therapies.

\section{Conclusion}

AITL is an infrequent hematological malignancy with variable but nonspecific presentations. AITL associated dysimmunity may lead to multi-organ involvement, while the presence of autoantibodies, cryoglobulinemia and monoclonal gammopathy may conceal AITL as the underlying disorder. A negative test result on serum cryoglobulin does not rule out cryoglobulinemia. Cryoglobulinemic nephropathy is most often associated with MPGN but it may also manifest as other histopathology. Knowledge and awareness of the features of AITL and its pathomechanism may alert clinicians to its early diagnosis and management.

\section{Abbreviations}

AITL: Angioimmunoblastic T cell lymphoma; AILD: Angioimmunoblastic lymphadenopathy with dysproteinemia; CN: Cryoglobulinemic nephropathy; DPGN: Diffuse proliferative glomerulonephritis; GC: Germinal center; IHD: Intermittent hemodialysis; MP: Methylprednisolone; MPGN: Membranoproliferative glomerulonephritis; NHL: Non-Hodgkin's Iymphoma; PE: Plasma exchange; PTCL: Peripheral T cell lymphoma; RTX: Rituximab; Tfh: Helper T cell

\section{Acknowledgements}

None.

\section{Authors' contributions}

Conception, study design, drafting of manuscript: $\mathrm{XYL}$; Data acquisition and tabulation: HYH; Pathology diagnosis: SLY; Critical review and revision: PP.

The authors read and approved the final manuscript.

Funding

None.

Availability of data and materials

The authors affirm that all the data supporting our findings are included in the manuscript.

Ethics approval and consent to participate

Not applicable.

Consent for publication

Written informed consent was obtained from the patient for publication of this case report. A copy of the written consent is available for review by the editor of this journal.

\section{Competing interests}

The authors declare that there are no competing interests.

\section{Author details}

${ }^{1}$ Department of Nephrology, University of Hong Kong - Shenzhen Hospital, Shenzhen, China. ${ }^{2}$ Department of Kidney Pathology, Guangzhou KingMed Center for Clinical Laboratory, Guangzhou, China. ${ }^{3}$ Department of Medicine, University of Hong Kong - Queen Mary Hospital, Pokfulam Road, Hong Kong, China.

Received: 2 June 2020 Accepted: 26 October 2020

Published online: 07 November 2020

\section{References}

1. Rudiger T, Weisenburger DD, Anderson JR, Armitage JO, Diebold J, MacLennan KA, Nathwani BN, Ullrich F, Muller-Hermelink HK. Non-Hodgkin's lymphoma classification P: peripheral T-cell lymphoma (excluding anaplastic large-cell lymphoma): results from the non-Hodgkin's lymphoma classification project. Ann Oncol. 2002;13(1):140-9.

2. Federico M, Rudiger T, Bellei M, Nathwani BN, Luminari S, Coiffier B, Harris $\mathrm{NL}$, Jaffe ES, Pileri SA, Savage KJ, et al. Clinicopathologic characteristics of angioimmunoblastic T-cell lymphoma: analysis of the international peripheral T-cell lymphoma project. J Clin Oncol. 2013;31(2):240-6.

3. Lachenal F, Berger F, Ghesquieres H, Biron P, Hot A, Callet-Bauchu E, Chassagne C, Coiffier B, Durieu I, Rousset H, et al. Angioimmunoblastic T-cell lymphoma: clinical and laboratory features at diagnosis in 77 patients. Medicine (Baltimore). 2007;86(5):282-92.

4. Mourad N, Mounier N, Briere J, Raffoux E, Delmer A, Feller A, Meijer CJ, Emile JF, Bouabdallah R, Bosly A, et al. Clinical, biologic, and pathologic features in 157 patients with angioimmunoblastic T-cell lymphoma treated within the Groupe d'Etude des Lymphomes de I'Adulte (GELA) trials. Blood. 2008;111(9):4463-70.

5. Tokunaga T, Shimada K, Yamamoto K, Chihara D, Ichihashi T, Oshima R, Tanimoto M, Iwasaki T, Isoda A, Sakai A, et al. Retrospective analysis of prognostic factors for angioimmunoblastic T-cell lymphoma: a multicenter cooperative study in Japan. Blood. 2012;119(12):2837-43.

6. de Leval L, Rickman DS, Thielen C, Reynies A, Huang YL, Delsol G, Lamant L, Leroy $\mathrm{K}$, Briere J, Molina T, et al. The gene expression profile of nodal peripheral T-cell lymphoma demonstrates a molecular link between angioimmunoblastic T-cell lymphoma (AITL) and follicular helper T (TFH) cells. Blood. 2007;109(11):4952-63.

7. Qin L, Waseem TC, Sahoo A, Bieerkehazhi S, Zhou H, Galkina EV, Nurieva R. Insights into the molecular mechanisms of $\mathrm{T}$ follicular helper-mediated immunity and pathology. Front Immunol. 2018;9:1884.

8. Lunning MA, Vose JM. Angioimmunoblastic T-cell lymphoma: the manyfaced lymphoma. Blood. 2017;129(9):1095-102.

9. Ambrosio MR, Rocca BJ, Ginori A, Onorati M, Fabbri A, Carmellini M, Lazzi S, Tripodi S. Renal infarction due to polyarteritis nodosa in a patient with 
angioimmunoblastic T-cell lymphoma: a case report and a brief review of the literature. Diagn Pathol. 2012;7:50.

10. Li J, Umakanathan M, P'ng CH, Varikatt W, Kwok F, Lin MW, Vucak-Dzumhur M. Cryoglobulinemic glomerulonephritis associated with nodal and renal infiltration by T-cell lymphoma of T-follicular helper phenotype: a case report. Am J Kidney Dis. 2018;72(4):606-11.

11. Richmond J, Sherman RS, Diamond HD, Craver LF. Renal lesions associated with malignant lymphomas. Am J Med. 1962;32:184-207.

12. Dhanapriya J, Dineshkumar T, Sakthirajan R, Surendar D, Gopalakrishnan N, Balasubramaniyan T. Paraneoplastic glomerulopathies associated with hematologic malignancies. Saudi J Kidney Dis Transpl. 2018;29(2):452-5.

13. Cohen LJ, Rennke HG, Laubach JP, Humphreys BD. The spectrum of kidney involvement in lymphoma: a case report and review of the literature. Am J Kidney Dis. 2010;56(6):1191-6.

14. Da'as N, Polliack A, Cohen Y, Amir G, Darmon D, Kleinman Y, Goldfarb AW, Ben-Yehuda D. Kidney involvement and renal manifestations in nonHodgkin's lymphoma and lymphocytic leukemia: a retrospective study in 700 patients. Eur J Haematol. 2001;67(3):158-64.

15. Li SJ, Chen HP, Chen YH, Zhang LH, Tu YM, Liu ZH. Renal involvement in nonHodgkin lymphoma: proven by renal biopsy. PLoS One. 2014;9(4):e95190.

16. Zeppa P, Marino G, Troncone G, Fulciniti F, De Renzo A, Picardi M, Benincasa G, Rotoli B, Vetrani A, Palombini L. Fine-needle cytology and flow cytometry immunophenotyping and subclassification of non-Hodgkin lymphoma: a critical review of 307 cases with technical suggestions. Cancer. 2004;102(1):55-65.

17. Dogan A, Attygalle AD, Kyriakou C. Angioimmunoblastic T-cell lymphoma. Br J Haematol. 2003;121(5):681-91.

18. Sallah S, Gagnon GA. Angioimmunoblastic lymphadenopathy with dysproteinemia: emphasis on pathogenesis and treatment. Acta Haematol. 1998:99(2):57-64.

19. Trejo O, Ramos-Casals M, Garcia-Carrasco M, Yague J, Jimenez S, de la Red G, Cervera R, Font J, Ingelmo M. Cryoglobulinemia: study of etiologic factors and clinical and immunologic features in 443 patients from a single center. Medicine (Baltimore). 2001;80(4):252-62.

20. Wood WG, Harkins MM. Nephropathy in angioimmunoblastic lymphadenopathy. Am J Clin Pathol. 1979;71(1):58-63.

21. Platzer $E$, von Roemeling R, Kaduk B, Meinl U. Disease-specific renal failure in angioimmunoblastic lymphadenopathy - remission by high dose prednisolone. A case report (author's transl). Klin Wochenschr. 1981;59(10):509-16.

22. Bhat JG, Kerpen HO, Murthy PS, Horowitz LJ, Valderrama E. Angioimmunoblastic lymphadenopathy, Bence Jones proteinuria, and acute renal failure. Arch Intern Med. 1981;141(10):1373-4.

23. Resegotti L, Rua S, Dolci C, Grosso B, Pistone M, Testa D. Polyclonal lymphadenopathy presenting as plasma cell leukemia with reversible renal insufficiency. Acta Haematol. 1983;70(1):54-8.

24. Bello I, Paya C, Ruilope LM, Jimenez E, Rodicio JL. Angioimmunoblastic lymphadenopathy and transient Fanconi syndrome. Nephron. 1985;39(3):275-6.

25. Bignon YJ, Janin-Mercier A, Dubost JJ, Ristori JM, Fonck Y, Alphonse JC, Sauvezie BJ. Angioimmunoblastic lymphadenopathy with dysproteinaemia (AILD) and sicca syndrome. Ann Rheum Dis. 1986;45(6):519-22.

26. Staszewski H, Kumar G, Mishriki Y. Minimal change disease as the etiology of the nephrotic syndrome in a patient with angioimmunoblastic lymphadenopathy. Med Pediatr Oncol. 1988;16(3):206-9.

27. Yamazaki Y, Inaba S, Nemoto T, lizuka K, Fujikawa T, Horiguchi J, Yamada H. Acute renal failure due to endocapillary proliferative glomerulonephritis in a patient with IBL-like T-cell lymphoma. Rinsho Ketsueki. 1991;32(7):796-801.

28. Nakamoto $Y$, Hashimoto $K$, Chubachi A, Miura AB, Watanuki T, Konno A. Acute interstitial nephritis with symmetric enlargement of the lacrymal and salivary glands and systemic lymphadenopathy. Am J Nephrol. 1993;13(1):73-7.

29. Duwaji MS, Shemin DG, Medeiros L, Esparza AR. Proliferative glomerulonephritis with unusual, organized, cylindrical deposits associated with angioimmunoblastic lymphadenopathy-like T-cell lymphoma. Arch Pathol Lab Med. 1995;119(4):377-80.

30. Lim AK, Ferreira MA, Majumdar A, Wheeler DC, Lipkin GW. Renal amyloidosis and angioimmunoblastic lymphadenopathy. Nephrol Dial Transplant. 1998;13(2):453-4.

31. Hamidou MA, El Kouri D, Audrain M, Grolleau JY. Systemic antineutrophi cytoplasmic antibody vasculitis associated with lymphoid neoplasia. Ann Rheum Dis. 2001;60(3):293-5.

32. Goto A, Takada A, Yamamoto S, Notoya A, Mukai M. Angioimmunoblastic Tcell lymphoma with renal involvement: a case report of direct bilateral kidney invasion by lymphoma cells. Ann Hematol. 2004;83(11):731-2.
33. De Samblanx H, Verhoef G, Zachee P, Vandenberghe P. A male with angioimmunoblastic T-cell lymphoma and proliferative glomerulonephritis. Ann Hematol. 2004;83(7):455-9.

34. Miura N, Suzuki K, Yoshino M, Kitagawa W, Yamada H, Ohtani H, Joh K, Imai $\mathrm{H}$. Acute renal failure due to IgM-lambda glomerular thrombi and MPGNlike lesions in a patient with angioimmunoblastic T-cell lymphoma. Am J Kidney Dis. 2006:48(1):e3-9.

35. Argov O, Charach G, Weintraub M, Shtabsky A. Angioimmunoblastic T-cell lymphoma presenting as giant kidneys: a case report. J Med Case Rep. 2009;3:9258.

36. Togashi M, Wakui H, Kodama K, Kameoka Y, Komatsuda A, Nimura T, Ichinohasama R, Sawada K. Angioimmunoblastic T-cell lymphoma and membranous nephropathy: a still unreported association. Clin Exp Nephrol. 2010;14(3):288-93.

37. Nanno S, Nakamae H, Kuwamura Y, Ishimura E, Sakabe M, Inaba A, Koh S, Yoshimura T, Nishimoto M, Hayashi Y, et al. Angioimmunoblastic T cell lymphoma complicated with endocapillary proliferative glomerulonephritis. Rinsho Ketsueki. 2013;54(7):658-63.

38. Harada Y, Sakai K, Asaka S, Nakayama K. Angioimmunoblastic T-cell lymphoma associated with IgA nephropathy. Intern Med. 2017:56(1):85-9.

39. Chen YP, Cheng H, Rui HL, Dong HR. Cryoglobulinemic vasculitis and glomerulonephritis: concerns in clinical practice. Chin Med J. 2019;132(14):1723-32.

40. Brouet JC, Clauvel JP, Danon F, Klein M, Seligmann M. Biologic and clinical significance of cryoglobulins. A report of 86 cases. Am J Med. 1974;57(5):775-88.

41. Terrier B, Karras A, Kahn JE, Le Guenno G, Marie I, Benarous L, Lacraz A, Diot E, Hermine O, de Saint-Martin L, et al. The spectrum of type I cryoglobulinemia vasculitis: new insights based on 64 cases. Medicine (Baltimore). 2013;92(2):61-8.

42. Herrera GA, Turbat-Herrera EA. Renal diseases with organized deposits: an algorithmic approach to classification and clinicopathologic diagnosis. Arch Pathol Lab Med. 2010;134(4):512-31.

43. D'Amico G, Colasanti G, Ferrario F, Sinico RA. Renal involvement in essential mixed cryoglobulinemia. Kidney Int. 1989;35(4):1004-14.

44. Ben-Bassat M, Boner G, Rosenfeld J, Pick Al, Kahana M, Hazaz B, Hochman B. The clinicopathologic features of cryoglobulinemic nephropathy. Am J Clin Pathol. 1983;79(2):147-56.

45. Nasr SH, Markowitz GS, Reddy BS, Maesaka J, Swidler MA, D'Agati VD. Dysproteinemia, proteinuria, and glomerulonephritis. Kidney Int. 2006;69(4):772-5.

46. Motyckova G, Murali M. Laboratory testing for cryoglobulins. Am J Hematol. 2011;86(6):500-2.

47. Leung N, Bridoux F, Batuman V, Chaidos A, Cockwell P, D'Agati VD, Dispenzieri A, Fervenza FC, Fermand JP, Gibbs S, et al. The evaluation of monoclonal gammopathy of renal significance: a consensus report of the international kidney and monoclonal Gammopathy research group. Nat Rev Nephrol. 2019;15(1):45-59.

48. Muchtar E, Magen H, Gertz MA. How I treat cryoglobulinemia. Blood. 2017; 129(3):289-98

49. Delfau-Larue $M H$, de Leval L, Joly B, Plonquet $A$, Challine $D$, Parrens $M$, Delmer A, Salles G, Morschhauser F, Delarue R, et al. Targeting intratumoral $B$ cells with rituximab in addition to CHOP in angioimmunoblastic T-cell Iymphoma. A clinicobiological study of the GELA. Haematologica. 2012; 97(10):1594-602.

\section{Publisher's Note}

Springer Nature remains neutral with regard to jurisdictional claims in published maps and institutional affiliations.

\section{Ready to submit your research? Choose BMC and benefit from:}

- fast, convenient online submission

- thorough peer review by experienced researchers in your field

- rapid publication on acceptance

- support for research data, including large and complex data types

- gold Open Access which fosters wider collaboration and increased citations

- maximum visibility for your research: over $100 \mathrm{M}$ website views per year

At BMC, research is always in progress.

Learn more biomedcentral.com/submissions 